\title{
AKADEMICKÁ ÚSPĚŠNOST U DĚTÍ A DOSPÍVAJÍCÍCH S NADVÁHOU A OBEZITOU ${ }^{1}$
}

\author{
Hana Včelařová, Hana Frydrychová
}

\begin{abstract}
Abstrakt
Vzestup obezity v posledních letech vedl $\mathrm{k}$ řadě studií, které se zabývaly vztahy mezi tělesnou hmotností v dětství a dosaženým vzděláním, výší příjmu a jinými socioekonomickými aspekty $v$ dospělosti. Př́spěvek navazuje na výzkumy, které byly zaměřeny především na akademickou úspěšnost dětí a dospívajících s nadváhou a obezitou. Tyto výzkumy usilovaly o socioekonomickou, psychosociální a zdravotní analýzu příčin a důsledků školního prospěchu u této části populace. Cílem príspěvku je porovnání a shrnutí výstupů z těchto studií.

Úvodní část přináší informace o aktuálním výskytu nadměrné tělesné hmotnosti u dětské i dospělé populace ve světě a v naší zemi. Epidemie nadváhy a obezity a její posun do nižšího věku je spojován s větším ohrožením zdraví a s přidruženými vývojovými komplikacemi u současné i u budoucích generací: z uvedených důvodů nejde o okrajové téma.

Akademickou úspěšnost dětí a dospívajících s nadváhou a obezitou nelze zkoumat bez znalostí faktorů, které jsou pro rozvoj dětské nadměrné hmotnosti významné. Poznatky o časté a výsledné podobě socioekonomických a vzdělanostních výsledků u populace s nadváhou a obezitou v dospělém věku jsou samy o sobě vysvětlením toho, $\mathrm{z}$ jakých důvodů je nutné se zabývat výsledky podobně zaměřených výzkumů z předcházejících vývojových období. Závěrečné shrnutí je doplněno o náměty, jichž by bylo vhodné využít v tematicky navazujících studiích.
\end{abstract}

Klíčová slova: akademická úspěšnost, děti, dospívající, nadváha, obezita, sociálně ekonomický status

\section{ACADEMIC PERFORMANCE IN CHILDREN AND ADOLESCENTS WITH OVERWEIGHT AND OBESE}

\begin{abstract}
The rise of obesity in recent years has led to a number of studies about relationship between weight in childhood and the reached level of education, income and other socio-economic aspects in adulthood. This article follows previous researches which were focused mostly on the academic success of children and adolescents with overweight and obesity. These researches aimed for the socio-economic, psychosocial and health analysis of causes and consequences of school success rate within this part of population. The aim of this article is to compare and summarize the outputs of these studies.

The introductory part brings information about current occurrence of overweight in children and adults population in the world and in our country. The epidemic of overweight and obesity and its movement to a lower age is connected with greater risks for health and associated developmental complications for current and future generations, therefore this is not a marginal issue.
\end{abstract}

\footnotetext{
${ }^{1}$ Podpořeno z grantu: IGA/FHS/2015/007
} 
The academic success of children and adolescents with overweight and obesity cannot be studied without the knowledge of factors, which are significant for the development of children obesity. Findings about common and final form of socioeconomic and educational results within the population with overweight and obesity are themselves the explanation of why it is important to address the outputs of similarly focused researches form previous developmental periods. The final summary is supplemented by suggested topics, which should be used in thematically following studies.

Keywords: academic performance, children, adolescents, overweight, obesity, socioecononomic status

Došlo do redakce: 23.1 .2017

Schváleno k publikaci: 25. 10. 2017

\section{Úvod}

Celosvětová epidemie obezity představuje závažný zdravotní a sociálně-ekonomický problém. $\mathrm{V}$ roce 2014 bylo na světě 1,9 miliardy lidí s nadváhou, přičemž 600 miliónů z nich bylo obézních (WHO, 2015). Nejvýznamněji se pandemie obezity projevila v dětské populaci.

Kunešová et al. (2014) informují o vzestupu nadváhy u českých sedmiletých dětí od roku 1951 do 2001, zastavení trendu u této věkové skupiny bylo konstatováno v období 20012010. Dle dalších českých výzkumů trpí v ČR nadváhou každé čtvrté dítě, obezitou každé sedmé dítě a zastoupení extrémní obezity v dětské populaci je 4,7 \% (Marinov, 2014).

Rozvoj dětské obezity bývá pozvolný. Nadměrná hmotnost u dětí je podmíněna př́tomností proobezitogenního genomu, obezitogenním prostředím ( $\mathrm{v}$ rodině, $\mathrm{v}$ komunitě) a pozitivní energetickou bilancí (Marinov et al., 2012). Časnější nástup obezity v populaci znamená posun zdravotních obtíží do nižšího věku. Dokonce i dětská obezita může být provázena zdravotními problémy. Čeští odborníci sice informují i o metabolicky zdravých jedincích s obezitou, předpokládá se však, že jde o přechodný stav (Hainer, Zamrazilová a AldhoonHainerová, 2015).

Dle zahraničních i tuzemských autorů jsou dětská nadváha a obezita provázeny psychosociálními obtížemi (např. Balharová a Jurčová, 2006; Gudersen, Mahatmya, Garasky a Lohman, 2011). Tato část dětské populace čelí více či méně otevřeným projevům diskriminace nebo aspoň podceňování, asi nejvýrazněji ze strany vrstevníků. Takové zkušenosti jsou demotivující, mohou vést k vyhýbání se nepř́jemným situacím (např. k vyšším absencím ve škole) a k postupnému zhoršování školního prospěchu (Kaestnera a Grossman, 2009). Podobné a další prríklady jsou v zahraniční literatuře označovány jako mnohonásobné cesty obezity, které vedou ke slabým školním výsledkům.

\section{Souvislosti mezi tělesnou hmotností a dosaženou úrovní vzdělání v dospělém věku}

Významné vztahy mezi tělesnou hmotností a dosaženou úrovní vzdělání v dospělosti byly nalezeny ve více studiích. Nezřídka se jednalo o ekonomicky, zdravotně nebo ještě jinak zaměřené studie, které zkoumaly souvislosti mezi různě definovanými skupinami populace, mírou vytrvalosti, vynaloženého úsilí a výslednou úspěšností při vzdělávání (Komlos, Smith a Bogin, 2004; Taras a Potts-Datema, 2005; Truong a Sturm, 2005; Truong a Sturm, 2014). 
Ekonomické studie přicházely s výklady o významu rodičovského vzdělání, rodinného př́ijmu, etnika, nebo dokonce sousedství, což bylo (nejen následně) analyzováno v sociálně a v psychologicky zaměřených výzkumech.

Také výsledky amerického zdravotního průzkumu Behavioral Risk Factor Surveillance System za období 1984-2008 (dále jen BRFSS) ukázaly, že úroveň dosaženého vzdělání a nadměrná tělesná hmotnost na populační úrovni korelují, ačkoli síla této korelace není u všech vrstev stejná (Centers for Disease Control and Prevention, 2008; Truong a Sturm, 2014).

Výše uvedená zjištění vyvolala otázky, zda dětská obezita může souviset se školními výsledky, popř. s kognitivními schopnostmi a výsledně i s úrovní dosaženého vzdělání.

Navazujeme na již zmíněný průzkum BRFSS z období 1984-2008 (Centers for Disease Control and Prevention, 2008; Truong a Sturm, 2014). Výsledky zahrnují přibližně 3,9 milión údajů od respondentů, s nimiž byl navázán kontakt vytáčením náhodných telefonních čísel. Při zpracovávání dat bylo přihlíženo ke změnám v průběhu času, aby nedošlo ke zkreslení výsledků (vlivem stárnutí populace, migrace aj.). Ukázalo se, že v každém roce za posledních dvacet let nalézáme spojení mezi nižšími vzdělávacími výsledky a vyšší hodnotou průměrného BMI. Výsledky bohužel ukazují, že hodnota průměrného BMI roste v průběhu času stabilně ve všech podskupinách, míra vzrůstu je dost podobná, i když podskupiny s vysokoškolským vzděláním jich zatím dosahují později. Truong a Sturm (2005), kteří srovnávali v omezeném časovém úseku téže studie (1986-2002) trendy váhových zisků napříč sociodemografickými skupinami u 1,88 miliónu dospělých, učinili podobné nálezy: průměrné BMI je vždy vyšší pro níže vzdělané a pro nižší př́ijmové skupiny. Současně konstatovali, že pokud srovnávají rozdíly mezi průměrnými hodnotami BMI např́č všemi vzdělanostními skupinami za více než deset let, potom dochází k vyrovnávání těchto hodnot, ačkoli je vysokoškolské vzdělání stále ještě považováno za protektivní faktor. Vzorec pro váhový zisk u žen je asi jiný než u mužủ, zřejmě i z hlediska jejich zapojení do práce (Truong a Sturm, 2005).

\section{Nadměrná tělesná hmotnost a akademická úspěšnost $v$ dětství, $v$ adolescenci a na počátku mladé dospělosti}

Dosud uváděné poznatky o spojení vzdělanostního statusu a obezity se týkaly dospělé populace. Klíčovými fázemi pro výslednou úroveň vzdělání jsou dětství, adolescence a mladá dospělost. V následujícím textu se pokusíme interpretovat výsledky reprezentativních studií, vztahujících se $\mathrm{k}$ této tématice a $\mathrm{k}$ vývojovým obdobím. Některé studie nelze zařadit do jednoho období, protože procházejí více vývojovými fázemi současně (např. Schwimmer et al., 2003).

\section{Předškolní věk}

U dětí předškolního věku ještě neužíváme obecně přijímaná kritéria školní úspěšnosti, jakým je např. školní prospěch. Jak v následujících výzkumech uvidíme, většina autorů proto srovnává výkony dětí tohoto věku v různě zaměřených kognitivních zkouškách.

Datar, Sturm a Magnabosco (2004) v rámci studií National Study of Kindergartens and First Graders a Early Childhood Longitudinal Study z roku 1988 zkoumali souvislosti mezi tělesnou hmotností u 11192 dětí a jejich výkonovými úspěchy v MŠ a v prvních ročnících základních škol. Výsledky dětí v jazykově a matematicky zaměřených zkouškách byly zkoumány ve vztazích ke zjišt'ovaným položkám socioekonomického statusu (dále jen SES), způsobu interakce mezi rodiči a dětmi, porodní váze dětí, míře fyzické aktivity a běžné době sledování televize. Ukázalo se, že z hlediska vztahu vůči výkonovým zkouškám převážilo vzdělání matek a etnická příslušnost význam tělesné hmotnosti. 
Autoři rovněž konstatovali, že statistická analýza jim nepomohla zjistit směr příčinnosti stejně jako mohla být nadváha významná pro školní výsledky, tak i slabší školní výsledky mohly být významné pro získání nadváhy.

Stejní autoři navázali na předcházející studii ještě zajímavějším výzkumem. Datar a Sturm (2006) opět v rámci studie The Early Childhood Longitudinal Study - Kindergarten Class (ECLS-K) z let 1988-89 zkoumali vztah mezi vývojem nadváhy a školními výsledky asi u 7000 dětí v USA při jejich vstupu do MŠ a na konci 3. tř́ídy. ${ }^{2}$ Zaznamenávali údaje o mnoha osobních i rodinných údajích - věku, pohlaví, etniku, porodní váze, rodinném př́ijmu, vzdělání matky, způsobech interakcí mezi rodiči a dětmi, o běžné době sledování televize aj. Dále zkoumali výsledky dětí v matematicky a jazykově zaměřených testech. Zaznamenávali výpovědi učitelů o behaviorálních projevech dětí na Škále sociálních dovedností (Social Skills Rating Scale) a o př́istupu k učení ze strany dětí nebo jejich rodin (omluvené i neomluvené absence, opakování třídy aj.). Zjistili, že posun od normální váhy směrem k nadváze od doby docházky do MŠ a během prvních tříd na ZŠ vede u děvčat k nižším výsledkům v obou testových skórech. Dívky, které v průběhu výzkumu nadváhu získávaly, vykazovaly zpočátku externalizované obtíže v chování (vztek, hádání se, fyzické střety s ostatními dětmi, rušení hry ostatních dětí aj.) a rovněž u nich byly pozorovány horší přístupy k učení. Na konci výzkumu projevovaly spíše internalizované obtíže v chování (nízké sebevědomí, smutek, úzkost). Dívky, které trpěly nadváhou po celou dobu výzkumu, projevovaly převážně internalizované obtíže v chování a neměly výrazné výkonové posuny v testech. U chlapců bylo zjištěno slabší spojení mezi posunem váhy a výsledky ve škole. Chlapci, kteří trpěli nadváhou po celou dobu výzkumu, projevovali menší míru externalizovaných obtíží v chování. Chlapci, kteří během doby výzkumu nadváhu získávali, měli rovněž méně externalizovaných obtíží v chování, ale více absencí ve škole. Děti, které měly nadváhu po celou dobu výzkumu, měly více absencí. Děti, které nadváhu v průběhu výzkumu získaly, častěji opakovaly ročník.

K nejčerstvějším výzkumům patří další dvě studie, vztahující se k předškolnímu věku. Afzal a Gortmaker (2015) zkoumali v longitudinální studii vztahy mezi obezitou a výkony u 2-8 letých dětí v kognitivních testech. V roce 1988 začali dle uvedených hledisek sledovat vývoj 2672 dvouletých dětí. Sběr dat z této první kohorty byl ukončen v roce 1994, tj. v době, kdy bylo dětem 6 let. Stejně postupovali při sběru dat z druhé kohorty v letech 1994-2001, kdy byl sledován vývoj 1991 dětí. Z hlediska př́tomnosti obezity byly děti řazeny do kategorií „nikdy obézní, „staly se obézními“, „vždy obézni'“ a „staly se neobézními.“

Hlavní výsledky tvořily standardizované skóry čtyř zkoušek metody „Peabody Individual Achievement Test“" (dále jen PIAT). Původní výsledky ukázaly významné spojení mezi obezitou a výsledky v testu PIAT. V první kohortě měly děti s obezitou horší matematické výsledky než děti, které nikdy obézní nebyly. Ve druhé kohortě byly matematické výsledky horší u dětí, které se staly obézními, než u dětí, které nikdy obézní nebyly. Dívky s obezitou měly slabší výsledky v jazykově zaměřených zkouškách než ty, které nikdy obézní nebyly. Po přizpůsobení výsledků sledovaným podmínkám domácího prostředí došlo k eliminaci původně významných rozdílů ve výkonech mezi skupinami dětí. Autoři dospěli k závěru, že není pravděpodobné, že by dětská obezita byla příčinou kognitivního výkonu.

\footnotetext{
${ }^{2}$ Mateřské školky, jak je známe u nás, v USA neexistují. Předškolní výchova není státem organizovaná a není zdarma. Poslední předškolní ročník, tzv. „kindergarten“, je však považován za součást základního vzdělání a je základními školami poskytován. Pětileté děti vstupují do jakýchsi př́pravných ročníků, které zatím neobsahují klasickou výuku, ale připravují se na ni z hlediska vhodného chování a spolupráce s ostatními žáky ve třídě.
} 
Pearce et al., (2016) ve svém příspěvku konstatují, že se ví jen málo o vývoji dětí, které již v předškolním věku nejsou zdravé (např. z důvodu nadváhy anebo obezity). Zkoumali vývoj 4-6letých dětí ( $\mathrm{n}=7533)$, které byly mírně subnormní nebo naopak s nadměrnou tělesnou hmotností z hlediska kritérií fyzického zdraví, duševní pohody, sociálních kompetencí, emocionální zralosti, komunikačních, jazykových a jiných kognitivních nebo obecných znalostí. Sběr dat byl realizován v rámci průzkumu „The Australian Early Development Census“", kdy jsou zaznamenávány vývojové charakteristiky australských dětí raného a předškolního věku. U dětí s mírně subnormní hmotností bylo zjištěno stejné riziko vývojové zranitelnosti jako u dětí s normální tělesnou hmotností. Podobně tomu bylo u dětí s nadváhou, u nichž byly nalezeny dokonce lepší jazykové a kognitivní znalosti. Děti s obezitou se jevily jako zranitelnější ve vztahu k fyzickému zdraví, duševní pohodě a sociálním kompetencím nebo v jedné nebo více dalších oblastech.

\section{Školní věk}

Ukázkou studií ze sociálně odlišných prostředí jsou další dvě práce. Mo-suwan et al. (1999) sledovali 1207 thajských dětí z 3. - 6. třídy (mladší/starší školní věk) a 587 dětí ze 7. - 9. třídy (adolescence). U všech dětí byly odborně změřeny hodnoty BMI, zjištěno vzdělání a zaměstnání rodičů, výše měsíčního příjmu a prospěchový průměr ze závěrečných zkoušek z matematiky a hlavního jazyka, které učitelé hodnotili na základě písemných zkoušek. Autoři zjistili, že u dětí s nadváhou a obezitou ve 3. - 6. tř́dě se významné odlišnosti v prospěchu neprojevily. Jinak tomu bylo u adolescentních dětí s obezitou a nadváhou v 7. - 9. třídě, které měly v závěrečných zkouškách z obou hlavních předmětů významně horší prospěch než děti s normální tělesnou hmotností (zejména chlapci).

Podobně i Chen et al. (2012) ve své šestileté longitudinální studii došli k závěru, že u 409 dětí, žijících na Taiwanu, se neprojevilo, že by změny v BMI hodnotách během 1. - 6. třídy ovlivnily jejich akademickou úspěšnost. Výška a váha dětí byly změřeny počátkem akademického roku, prospěch na konci školního roku, dále byla zjišstována míra absence, inteligenční kvocient (Barevné progresivní matice), některé položky socioekonomického statusu. Děti s obezitou měly obecně nižší školní výsledky i výsledky psychologického testu, ale nejednalo se o významné rozdíly. Odlišné psychosociální aspekty nadváhy a obezity ukazuje také výzkum 130 čínských dětí ve věku 9-14 let (Chen et al., 2014). Na základě předkládaných štíhlých nebo zavalitých siluet se děti vyjadřovaly $\mathrm{k}$ tomu, zda a do jaké míry by se chtěly stát kamarády dětí s takovou postavou. Ve srovnání s obrysy postav bez nadváhy byly dívčí postavy s nadváhou preferovány významně méně často, chlapecké objekty s nadváhou byly naopak voleny častěji. Autoři výzkumu konstatují, že stigma typické pro západní země nemusí platit pro čínskou kulturu.

Netradičním způsobem dokladují souvislost mezi hodnotami BMI a školními výsledky autoři další studie (Hollar et al., 2010). Informují o efektu dvouleté intervence (2004-2006) na základních školách na Floridě, které měly podobné demografické a SES charakteristiky (převážně nízkopříjmové rodiny). Intervence zahrnovala dietní opatření (formou bezplatných nebo cenově omezených obědů), toto bylo spojeno s výukou o zdravých principech výživy a se zvýšeným důrazem na složky fyzické aktivity. Očekával se dopad na hodnoty BMI percentilů a současně byly sledovány školní výsledky dětí. Autoři studie konstatují, že děti s obezitou o něco snížily hodnotu BMI percentilů, současně došlo k významnému zvýšení výkonů v matematicky orientovaných testech a k nevýznamnému zlepšení $\mathrm{i} v$ př́padě jazykově orientovaných zkoušek. 
Kamijo et al., (2012), kteří usilovali o porozumění vztahům mezi exekutivními funkcemi a úrovní BMI u 126 preadolescentních dětí ve věku 7-9 let, nalezli u dětí s vyšším BMI slabší výsledky v úkolech, které byly zaměřeny na schopnost inhibiční kontroly.

Ke studiím v oblasti evropského regionu patří práce Veldwijka et al., (2012), týkající se skupiny dětí mladšího školního věku (8-12 let) v celkovém počtu 4164 ve třech odlišných holandských městech. Autoři zkoumali souvislost mezi nadváhou a školní úspěšností dětí z hlediska tělesné hmotnosti. Za indikátory školního úspěchu byly považovány dva ukazatele - standardizovaný vzdělanostní test, který žáci na konci školního věku absolvovali a doporučení učitele, vztahující se ke studijním možnostem dětí na druhém stupni. Výška a váha dětí byla odborně změřena ve věku 8 a 12 let. Původní výsledky, které ukazovaly nízké skóre $\mathrm{v}$ testu a nižší učitelovo hodnocení vůči dětem s nadváhou, se projevily jako nevýznamné po přizpůsobení proměnným „vzdělání rodičưu (silný vliv), „vynechávání snídaní“" a „běžná doba sledování televize“.

\section{Adolescence a mladá dospělost}

Jedna z prvních takto zaměřených studií se zabývala průzkumem národně reprezentativního vzorku 10039 náhodně vybraných mladých lidí (16-24), jejichž vývoj byl sledován v rozmezí let 1981-1988 (Gortmaker et al., 1993). Současně byly sledovány údaje od skupiny lidí téhož věku s normální tělesnou hmotností, kteří však trpěli různými zdravotními obtížemi (cukrovka, vady páteře aj.). U všech respondentů byla každoročně zaznamenávána data, vztahující se k socioekonomickému statusu jejich původních rodin, k údajům o BMI, všichni respondenti prošli inteligenčním testem (Armed Forced Qualification Test) a byla jim administrována Rosenbergova škála sebepojetí. Dívky s nadměrnou tělesnou hmotností byly po sedmi letech méně často vdané, ukončily méně roků školní docházky, měly nižší př́ijem a častěji byly ohroženy chudobou. Muži s nadměrnou tělesnou hmotností byli méně často ženatí. U skupiny lidí s různými druhy tělesného onemocnění se významné rozdíly nebo souvislosti neprojevily.

Falkner et al. (2001) analyzoval data od 4742 amerických studentů a 5201 studentek 7., 9. a 11. stupně veřejných škol. Studenti anonymně zodpovídali dotazník, vztahující se k sociálním zkušenostem, ke stavu psychické pohody, ke vzdělávacím zkušenostem a k budoucím cílům. BMI studentů bylo vypočítáno na základě údajů, které studenti sdělili o své výšce a hmotnosti. Po přizpůsobení výsledků věku, etniku a položkám SES rodičů dívky s obezitou vypovídaly, že minulý týden strávily významně méně času se svými přáteli, v uplynulém roce častěji prožívaly emoční problémy, častěji prožívaly stavy beznaděje a častěji přiznávaly sebevražedné pokusy. Chlapci s obezitou cítili, že o ně jejich přátelé nestojí, přiznávali, že v minulém roce prožívali vážné problémy a spíše se považovali za špatné studenty. Dívky s obezitou vykazovaly velkou pravděpodobnost, že jejich prospěch bude ve srovnání s prospěchem dívek s normální tělesnou hmotností mnohem slabší, samy sebe označovaly za špatné studentky. Podobně tomu bylo u chlapců s obezitou, kteř́ se rovněž označovali za špatné studenty, a vyjadřovali se v tom směru, že počítají s předčasným ukončením školy.

K nejvýše uznávaným studiím, které se zabývají vztahy mezi obezitou a školními výsledky, patř́ studie finských autorů Mikkilä et al., (2003). Studie se zúčastnilo 60252 adolescentů ve věku od 14 do 16 let. Dotazníky se vztahovaly ke zdravotnímu stavu a zdravotnímu chování respondentů, k výživovým zvyklostem a k položkám SES zázemí. U dívek i chlapců autoři zjistili inverzní asociace mezi dobrými školními výsledky a tělesnou hmotností v pásmu obezity. Pro obě pohlaví platilo, že obezita a nespokojenost s tělesnou hmotností byly spojeny s ekonomickými problémy v rodině. $25 \%$ z chlapců s obezitou bylo se svými tělesnými mírami spokojeno. 
U dívek s obezitou bylo nalezeno spojení se slabými školními výsledky, s nízkou úrovní vzdělání jejich rodičů a $\mathrm{s}$ tím, že doma nemívaly večeře. U chlapců obezita souvisela $\mathrm{s}$ fyzickou pasivitou a se stravováním mimo školní jídelnu. Obezita a hmotnostní dissatisfakce byly nejsilněji spojeny s nezdravým chováním a s nízkým SES rodinného zázemí.

S prostředím severských zemí jsou spojeny výsledky práce Kristjánsona et al., (2008), kteří realizovali studii založenou na populačním vzorku 6346 islandských adolescentů ve věku 1415 let. BMI bylo zjištováno na základě sdělení studentů o výšce a váze, dále byly zaznamenávány údaje o pohlaví, rodinné struktuře (,doma bydlíš - s oběma rodiči, s matkou a partnerem, jiné složení rodiny“ aj.), vzdělání rodičů („začal studovat SŠ““, „získal VŠ diplom“ atd.), o miřre absence ve škole, o fyzické aktivitě (,kolik hodin týdně se věnuješ takto zaměřeným činnostem mimo školu“ aj.). Výživové zvyklosti byly zjišt’ovány dotazy typu ,jak často jíš hamburger" aj. Míra sebevědomí byla zjišt'ována Rosenbergovou škálou sebehodnocení. Hlavní proměnnou však byla akademická úspěšnost, která je odlišně hodnocena než v naší zemi a studenti o ní sami informovali. Autoři i v př́ípadě této studie zjistili, že nižší BMI, vyšší míra fyzické aktivity a dobré dietní návyky byly prediktivní vůči vyšším akademickým úspěchům. Na rozdíl od výzkumů v USA nebylo zjišt’ováno etnikum nebo náboženská př́islušnost, protože zdejší populace byla z těchto hledisek v době výzkumu dosti homogenní. Neprojevil se zde velký vliv rodičovského vzdělání. Byla nalezena souvislost mezi zdravým chováním a vyšším sebevědomím.

K obohacení dosud získaných poznatků přispěl výzkum adolescentů (14-17 let) v jižní Itálii (Barone et al., 2010). Autoři nalezli silné a robustní pozitivní asociace mezi obezitou a neúspěšným ukončením školní docházky $s$ významnými genderovými diferencemi $v$ povaze tohoto vztahu. Dále se projevily souvislosti se vzděláním rodičů, $\mathrm{s}$ oběma rodiči v rodině, se životním stylem rodiny a také s některými místními podmínkami, např. u mladých žen se zdála být významná okolnost, zda bydlí na pobřeží atd.

Laitinen a spolupracovníci, (2002), sledovali v longitudinální studii 9754 dětí narozených v roce 1966 v severním Finsku v 1., 14., a 31. roce života. Byly zjišt’ovány údaje o BMI (ve 14. letech a v 31. roce života), některé položky SES původní rodiny, současný rodinný stav, školní výsledky v 16. letech, pracovní anamnéza, zaměstnanost/nezaměstnanost v letech 1985-1997, výše př́íspěvků v nezaměstnanosti, místo bydliště ve 14. a v 31. roce života a počet dětí v 31. roce života. U subjektů obou pohlaví byla nadváha a obezita ve 14 . letech spojeny s nízkou úrovní vzdělání, ale ne s dlouhou nezaměstnaností do věku 31 let, se single stavem (u žen) nebo s rozvody (u žen) a s počtem dětí do věku 31 let (u žen).

\section{Shrnutí výstupů studií}

Již v jedné z prvních přehledových prací byla ve všech analyzovaných studiích nalezena vždy aspoň jedna negativní asociace mezi obezitou a školními výsledky: její autoři přesto nedospěli $\mathrm{k}$ jednotnému závěru (Taras a Potts Datema, 2005). Stejně tomu bylo v př́padě přehledové studie, která byla sepsaná o devět let později (Truong a Sturm, 2014). Z těchto a dalších výše uvedených prací je patrné, že výzkumy se liší rozsahem a kvalitou, počty respondentů (od několika desítek až po několik desítek tisíc), sociokulturním zázemím, sledovanými sociodemografickými činiteli, odlišnými způsoby zjišt’ování tělesných parametrů nadváhy a obezity, nejednotnou metodologií hodnocení školní úspěšnosti a popř. i dalších výkonových charakteristik dětí a dospívajících. O závěrečné shrnutí se přesto pokusíme.

Zřejmě nepřekvapuje, že existuje těsné propojení mezi rozvojem dětské obezity a rodinným životním stylem (např̀. Aldhoon-Hainerová, 2011). Vysoký vliv některých charakteristik rodinného zázemí, se projevuje i v prípadě vztahů mezi dětskou obezitou a školními výkony. 
Na měnící se podobu závislosti na rodinném zázemí v jednotlivých vývojových obdobích lze usuzovat také z toho, jaké sociodemografické činitele a jak silně se ve srovnání s jinými proměnnými (např. s hodnotou BMI) ve vztahu ke školním výsledkům prosazují.

U dětí na přelomu předškolního a školního věku (v závislosti na sledovaných proměnných konkrétního výzkumu) byly jako významné faktory identifikovány vzdělání matek, etnikum a některé další podmínky rodinného prostředí. Význam těchto činitelů pro výsledky v jazykově a v matematicky zaměřených zkouškách během longitudinálních výzkumů převážil význam tělesné hmotnosti.

Poměrně jistě lze tvrdit, že již v předškolním věku a během prvních let školní docházky se z hlediska vztahů mezi nadváhou/obezitou a školními/výkonovými výsledky projevují genderové rozdíly. Podobu genderových rozdílů zřejmě ovlivňuje, zda dítě k nadváze teprve spěje, nebo zda je nadváha u dítěte již rozvinuta. V období, během nějž se hmotnost dítěte na přelomu předškolního a školního věku k nadváze teprve posouvá, vykazuje chování dítěte více nestabilních nebo sociálně rizikových prvků. V tomto směru se dle studií jako více ohrožené jeví dívky, a to jak posunem k horším školním výsledkům, tak i posunem od původně externalizovaných k internalizovaným obtížím v chování.

Pearce et al. (2016), kteří realizovali výzkum v sociokulturně odlišném prostředí, potvrzují význam rodinného prostředí a jako jedni z mála objevují také silné kognitivní stránky předškolních dětí s nadváhou (ve srovnání se zdravými vrstevníky). Domníváme se, že v prrípadě dalšího rozpracování by podobné výstupy mohly být užitečné pro prevenci a jinou praxi. Kontrastní výsledky (z hlediska budoucího vzdělávání aj. vývojových rizik) se naopak potvrzují u předškolních dětí s již rozvinutou obezitou.

U dětí školního věku přetrvává z hlediska vztahů mezi tělesnou hmotností a vzdělanostními výsledky vliv vzdělání rodičů, rodinného př́ijmu a některých dalších podmínek rodinného prostředí. Výrazněji se profilují proměnné, jako jsou nepříznivé vztahy s vrstevníky a další, i v naší zemi ověřené, nebo zatím jen zvažované podmínky školního prostředí (edukace dětí o výživě, preventivní a intervenční programy, bezplatné obědy pro děti z nízkopř́ijmových rodin). Poznatků o významu pravidelných pohybových aktivit pro zlepšení exekutivních funkcí, které ovlivňují proces učení, je využíváno v rámci školních intervenčních strategií proti obezitě a prospěchovému selhání (Kamijo et al., 2012). Klinicky zaměřené studie informují o významu souběžně působících zdravotních komplikací, které se ve srovnání s předchozími obdobími objevují ve větší míře a mohou mít bud' př́ímou (např. spánkové apnoe, astma, syndrom ADHD), nebo neprímou (např. školní absence), souvislost se školními výkony (Kaestnera a Grossman, 2009).

Ve výzkumech vztahů mezi dětskou obezitou a vzdělanostními výsledky v sociokulturně odlišných zemích dochází někdy k posunu slabších školních výkonů znevýhodněných dětí do vyšších ročníků. Méně výrazně se projevuje vliv vzdělání rodičů a př́ijmu rodiny. $Z$ hlediska vztahu k akademické úspěšnosti se v některých př́padech ukázala jako více znevýhodňující př́slušnost $\mathrm{k}$ ženskému pohlaví než tělesná hmotnost. Je to vysvětlováno místními, silně diskriminujícími postoji vůči dívkám a ženám (Chen et al., 2012; Chen et al., 2014; Mosuwan et al., 1999).

V reprezentativních studiích severských zemí byly u adolescentních dívek i chlapců zjištěny inverzní asociace mezi obezitou, dobrým prospěchem a dobrou ekonomickou situací rodiny, pouze u dívek (v některých výzkumech) také s úrovní vzdělání rodičů a s podáváním večeří v domácím prostředí (Kristsjánson et al., 2008; Mikkilä et al., 2003). 
Stejné činitele se ukázaly jako významné ve vztazích mezi tělesnou hmotností a akademickou úspěšností i v př́padě některých výzkumů u amerických a italských adolescentních dětí s obezitou, které rovněž potvrzují více znevýhodňujících diferenciací u dívek (Barone et al., 2010; Falkner et al., 2001).

V americkém longitudinálním výzkumu, mapujícím vývoj od adolescence až po mladou dospělost, byly z hlediska vztahů mezi nadměrnou tělesnou hmotností a průběhem vzdělávání zjištěny více nepříznivé důsledky pro ženy v období mladé dospělosti (Gortmaker et al., 1993). Totéž se ukázalo i v př́padě severského longitudinálního výzkumu, kdy znevýhodňující sociální důsledky adolescentní obezity se zdály být silnější u žen. BMI v pásmu obezity bylo častěji konstatováno u dospělých subjektů obou pohlaví s nízkou úrovní vzdělání a u žen s dlouhou dobou nezaměstnanosti (Laitinen et al., 2002).

\section{Závěr}

Cílem studií o souvislostech mezi tělesnou hmotností, školními a jinými kognitivními výkony je rozšiŕǐit vědomosti o situaci a zdánlivě neexistujících překážkách dětí a dospívajících $\mathrm{s}$ nadváhou a obezitou na jejich cestě za vzděláním. Výstupy výzkumů mají vést k řešení a nikoli k nálepkování znevýhodněné části populace. Je zdůrazňováno, že školní i jiné kognitivní výkony dětí jsou ovlivňovány vnějšími i vnitřními faktory a příčinný vztah s tělesnou hmotností není pravděpodobný. Současně platí, že nadměrná tělesná hmotnost bývá školními neúspěchy často provázena: z tohoto důvodu na ni odborníci pohlížejí spíše jako na marker prospěchových obtíží (Truong a Sturm, 2014).

Z hlediska nasměrování budoucích výzkumů se setkáváme s několika opakujícími se motivy. Připomínána je nutnost systematičtějšího zmapování kognitivního vývoje dětí raného a předškolního věku, kdy by měly být identifikovány zvláštnosti (silné vývojové stránky, výhody nebo naopak ohrožení) nadváhy a obezity, zvláště jejích extrémních forem. Naděje jsou vkládány do longitudinálních studií, které budou pokračovat ve výzkumech rozvoje nadměrné tělesné hmotnosti v kontextu s vývojem školního prospěchu.

Poznatky o stresu v důsledku diskriminace zejména starších školních dětí s nadměrnou tělesnou hmotností obrací pozornost k výzkumům copingových strategií. Je zřejmé, že opakující se konfrontace s náročnými životními situacemi kladou zvýšené nároky na emoční i kognitivní varianty jejich zpracování. Nevhodné copingové mechanismy přispívají ke zhoršení školního prospěchu a tím i dalších aspektů kvality života. Domníváme se proto, že podobně zaměřené studie by mohly přinést užitečné výsledky.

\section{Literatura}

Afzal, A. S., \& Gortmaker, S. (2015). The relationship between obesity and cognitive performance in children: A longitudinal study. Childhood Obesity, 11, 466-474.

Aldhoon-Hainerová, I. (2009). Dětská obezita. Praha: Maxdorf.

Balharová, J., \& Jurčová, K. (2006). Psychosociální problémy dětí s nadváhou. Psychológia a patopsychológia diet'at'a, 41(4), 303-319.

Barone A., \& O'Higgins, N. (2010). Fat and out in Salerno and its province: Adolescent obesity and early school leaving in Southern Italy. Economics and Human Biology, 8, 44-57. doi: 10.1016/j.ehb.2009.09.003.

Centers for Disease Control and Prevention (2008). BRFSS: Behavioral Risk Factor Surveillance System, 1984-2008. https://www.cdc.gov/brfss/annual_data/annual_2008.htm 
Datar, A., Sturm, R. \& Magnabosco, J. L. (2004). Childhood overweight and academic performance: National Study of Kindergartens and First - Graders. Obesity Research, 12, 58-68.

Datar, A., \& Sturm, R. (2006). Childhood overweight and elementary school outcomes. International Journal of Obesity (London), 30, 1449-1460.

Falkner, N.H., Neumark-Sztainer, D., Jeffery, R.W., Beuhring, T., \& Resnick, M.D. (2001). Social, educational and psychosocial correlates of weight status in adolescents. Obesity Research, 9, 32-42.

Gortmaker, S. L., Must, A., Perrin, J. M., Sobol, A. M. \& Dietz, W. H. (1993). Social and economic consequences of overweight in adolescence and young adulthood. New England Journal of Medicine, 329, 1008-12.

Gudersen, C., Mahatmya, D., Garasky, S., \& Lohman, B. (2011). Linking psychosocial stressors and childhood obesity. Obesity Revue, 12, 54-63.

Hainer, V., Zamrazilová, H., \& Aldhoon-Hainerová, I. (2015). Existuje metabolicky zdravá obezita? Diabetologie - Metabolismus - Endokrinologie - Výživa, 18, 112-120.

Hollar, D., Messiah, S. E., Lopez-Mitnik, G., Phil, M., Hollar, L., Almon, M., \& Agatson, A.S. (2010). Effect of a two-year obesity prevention intervention on percentile changes in body mass index and academic performance in low-income elementary school children. American Journal of Public Health, $100,646-653$.

Chen, A., Yin, S., Tang, H., \& Wang, Z. (2014). An examination of the mere proximity effect of obesity discrimination in children in Chinese culture. Psychology Research, 4, 265-270. http://or.nsfc.gov.cn/bitstream/00001903-5/246216/1/1000013670000.pdf

Chen, L.-J., Fox, K. R., Ku, P.-W. \& Wang, C.-H. (2012), A Longitudinal Study of Childhood Obesity, Weight Status Change, and Subsequent Academic Performance in Taiwanese Children. Journal of School Health, 82: 424-431. doi:10.1111/j.1746-1561.2012.00718.x

Laitinen, J., Power, C., Sovio, U., \& Järvelin, M. R. (2002). Unemployment and obesity among adults in a northern Finland 1966 birth cohort. International Journal of Obesity and Metabolic Disorders, 26, $1329-1338$.

Kaestnera, R., \& Grossman, M. (2009). Effects of weight on children's educational achievement. Economics of Education Review, 28, 651-661.

Kamijo, K. N., Khan, A., Matthew, B. P., Scudder, M. R., Drollette, E. S., Raine, L. B., Evans, E. M., Castelli, D. M. \& Hilman, Ch. H. (2012). The relation of adiposity to cognitive control and scholastic achievement in preadolescent children. Obesity, 20, 2406-2411.

Komlos, J., Smith, P., \& Bogin, B. (2004). Obesity and the rate of time preference: is there a connection? Journal of Biosocial Science, 36, 209-219.

Kristjánsson, A. L., Sigfúsdóttir, I. D., \& Allegrante, J. P. (2010). Health behavior and academic achievement among adolescents: The relative contribution of dietary habits, physical activity, body mass index and self-esteem. Health Education \& Behavior, 37, 51-64.

Kunešová, M., Procházka, B., Vignerová, J., Pařízková, J., Braunerová, R., Guttenbergerová, T., Redlová, J., Zamrazilová, H., Hill, M., \& Šteflová, A. (2014). Prevalence nadváhy, obezity a podváhy u sedmiletých dětí v České republice od roku 1951. Časopis lékařủ českých, 153, 271-276.

Marinov, Z., Pastucha, D., Barčáková, U., Čepová, J., Divoká, J., Kalvachová, B., Kuželová, H., Málková, I., Nesrstová, M., Ptáček, R., Seeman, T., Vašǐčková, L., Vignerová, J., \& Zemková, D. (2012). Praktická dětská obezitologie. Praha: Grada.

Marinov, Z. (2014). Nadváha a běžná obezita v dětském věku - zdravotní výzva 21. století. Lékařské listy, 9, 21-24. 
Mikkilä, V., Lahti-Koski, M., Pietinen, P., \& Virtanen, S. M. (2003). Associates of obesity and weight dissatisfaction among Finnish adolescents. Public Health and Nutrition, 6, 49-56.

Mo-suwan, L., Lebel, L., Puetpaiboon, A., \& Junjana, C. (1999). School performance and weight status of children and young adolescents in a transitional society in Thailand. International Journal of Obesity, 23, 72-277.

Schwimmer, J. B., Burwinkle, T. B., \& Varni, J. W. (2003). Health-related quality of life of severely obese children and adolescents. Journal of the American Medical Association 289, 1813-1819.

Pearce, A., Scalzi, D., Lynch, J., \& Smithers, L. G. (2016). Do thin, overweight and obese children have poorer development than their healthy-weight peers at the start of school? Findings from a South Australian data linkage study. Early Childhood Research Quarterly, 35, 85-94.

Taras, H., \& Potts-Datema, W. (2005). Obesity and student performance at school. Journal of School Health, 75, 291-295.

Truong, K. D., Phil, M., \& Sturm, R. (2005). Weight gain trends across sociodemographic groups in the United States. American Journal of Public Health, 95, 1602-1606.

Truong, K., § Sturm, R. (2014). Schooling and human capital. In J. Cawley (Ed.), The Oxford Handbook of the Social Science of Obesity (517-530). OUP USA.

Veldwijk, J., Fries, M. C. E., Bemelmans, J. E., Nies, A. H., Smit, H. A., Koppelman, G. H., \& Wijga, A. H. (2012). Overweight and school performance among primary school children: The PlaMa Birth cohort Study. Obesity, 20, 590-596.

World Health Organization Media Centre. (2015). Fact Sheet No. 311. Obesity and Overweight, WHO. Dostupné z http://www.who.int/mediacentre/factsheets/fs311/en/

\section{Údaje o autorkách}

PhDr. Hana Včelařová pracuje na Ústavu pedagogických věd, Fakulty humanitních studií na UTB ve Zlíně. V předchozích letech vykonávala profesi dětské psycholožky na různých klinických a školských zařízeních. Je hlavní řešitelkou projektu IGA/FHS/2015/007. V současné době pracuje na disertační práci, vztahující se k obezitě.

Kontaktní údaje:

Adresa: Univerzita Tomáše Bati, Fakulta humanitních studií, Ústav pedagogických věd, Mostní 5392, 76001 Zlín

E-mail: vcelarova@fhs.utb.cz

Bc. Hana Frydrychová studuje obor Sociální pedagogika na Ústavu pedagogických věd, Fakulty humanitních studií Univerzity Tomáše Bati ve Zlíně. Studentka se rovněž aktivně angažuje jako vědecká síla Ústavu pedagogických věd. V roce 2016 se stala spoluřešitelkou projektu IGA/FHS/2015/007.

Adresa: Ústav pedagogických věd, Fakulta humanitních studií Univerzity Tomáše Bati ve Zlíně, Mostní 5392, 76001 Zlín.

E-mail: hanka.frydrychova@seznam.cz

Včelařová, H., Frydrychová, H. (2017). Akademická úspěšnost u dětí a dospívajících s nadváhou a obezitou. E-psychologie, 11(4), 19-29. Dostupné z http://e-psycholog.eu/pdf/vcelarova_frydrychova.pdf https://doi.org/10.29364/epsy302 